\title{
PREVENTION OF PSYCHOACTIVE SUBSTANCE USE AMONG YOUNG PEOPLE AS A SOCIALLY PEDAGOGICAL PROBLEM
}

\author{
Andrejs Vilks \\ Riga Stradins University, Latvia
}

\begin{abstract}
In the century of modern technologies the human behaviour models are changing, new types of addiction are developing, including addiction to processes (cyber, games addiction), as well as addiction to new substances. Among young people there is observed an increased spreading of new psychotropic substances, manufacturing of which is very simple, but their realization determines possibilities for a markedly great profit. In the cultural environment of young people the new traditions are formed, specific elements of subculture, positive attitude towards being able to use and apply something new. A new value system is developing with a sense of unlimited freedom and extensive rights. Along with the chances to buy and use new psychoactive substances, the changes occur also in the young people's psyche, affecting their emotional and physical condition. A new, socially-pedagogical approach is needed in restriction of the use of these new psychoactive substance.
\end{abstract}

Keywords: drugs; new psychoactive substances; prevention; socially peadgogical approach.

\section{Introduction}

The use of psychoactive substances among youngsters and children, including schoolchildren, is connected to a series of different conditions: 1) these substances are relatively widely available, in comparison to drugs, for instance, heroin, cocaine, etc. 2) considering the low cost of new psychoactive substances, almost anybody can get them, if having an irresistable interest to try them; 3 ) there is specific logistics for the spread of new psychoactive substances and modern management as to their importing, storage and realization in the territory of Latvia; 4) specificity of manufacturing of new psychoactive substances encourages wide possibilities to generate new productions which are not included into the List of Prohibited Substances; 5) the use of substances causes especially negative, and in many cases, irreversible physical and psychic consequences in their users; 6) there has not been worked out, nor accepted a special pedagogic and preventive methodology for actions to be taken with youngsters and children - the new psychoactive substance users. In 2015, according to the data of the Information Centre of the Ministry of the Interior, $3613(+817)$ criminal offenses were registered in relation to the circulation of illegal drugs and psychotropic substances, which was by $27,7 \%$ more than in the 
Andrejs Vilks. Prevention of Psychoactive Substance use among Young People as a Socially Pedagogical Problem

previous year of the same period. Their proportion was $7,6 \%$ of the totally registered criminal offenses nationwide in 2015 (Pārskats, 2016).

In 2015 in Latvia there were registered 491 new cases of psychoactive substance seizures. Besides, there was encountered a fast increase of circulation of medicines containing psychotropic substances, affirmed by the number of seizures registered - $554(+332)$.

\section{Concept and essence of narcotic and psychoactive substances}

Narcotic substances include all natural and synthetic drugs, psychotropic and toxic substances which possess one common feature - to change a man's psychologic condition in a subjectively pleasant direction, it is, to soothe the pain, to cause euphoria, to promote the stimulation of the body functions and to produce perception disorders with illusions and hallucinations (Konovālovs et. al. 1995).

Ammendments to the Law „Of narcotic drugs, psychotropic substances and drug legal procedures for the circulation" says, that a new psychoactive substance is a new substance in a pure form or in a preparation, which is not presented according to the Single Convention on Narcotic Drugs, 30 March, 1961 and can generate a comparable threat to health like the substances listed in the schedule I, II, or IV of the Convention mentioned, or also as a new psychotropic substance in a pure form or in a preparation, which is not listed in February 21,1971 Single Convention on Psychotropic Substances and can generate comparable threat to health as the substances listed in the schedule I, II, III or IV of the Convention mentioned (Likums "Par narkotisko un psihotropo vielu un zāļu likumīgās aprites kārtību", 1996). The new psychoactive substances are unidentified and also illegal intoxicating substances, store drugs or intoxicating herbs.

„These intoxicating herbs are psychoactive - it means, that they change thinking, the senses and the behaviour. Their effect on a person's physical and mental health is unpredictable and there is a risk to become addicted (Legālās un nelegālās apreibinošās vielas)". New psychoactive substances are sold as herbal mixtures, thus hiding the real contents of the mixture. Herbal mixtures are sold by different names, for instance, „Spice”, „Spice Diamond”, „Spice Gold”, „Spice Silver”, „Spice Arctic”, „Genie Incense”, „Spice Diamond Spirit”, „Spice Tropical Synergy” (Sintētiskie kanaboīdi). Among the new psychoactive substances one should mention the use of gamma - hydroxybutyrate (GHB) for illegal purposes - its manufacturing, its use in a pure form as means of intoxication. The situation is made hard by the fact that GHB is not enlisted into the Internationally Controlled Substances, besides GHB is the substance legally 
used in the chemical industry, which is imported in Latvia in the contents of different mixtures. Thus, it is not possible to include GHB into the lists of controlled narcotic substances, psychotropic substances and their precursors, as a result, the law-enforcement institutions have no possibility to provide control over the substance track, as well as to remove the substance from the circulation.

We may encounter different definitions of the concept „new psychoactive substances" - substances whose action changes the type how people feel, think or behave" (Sargi sevi - narkotiskās un psihotropās vielas ). They, by their nature, imitate the traditional effect caused by narcotic substances and are sold legally as well. Since 2004, the annual number of reports on new synthetic substances increases. If in 2004 there were reports on 15 new substances, then in 2014 the number of reports had increased already up to 101. At present, in fact, each year there are reports of more than 100 new synthetic narcotic substances.

\section{Effect of new psychoactive substances on the human body}

In the law „Of narcotic drugs, psychotropic substances and drug legal procedures for the circulation" it is precisely defined, that the new psychoactive substances are new narcotic or psychotropic substances in a pure form or in a preparation and they can generate comparable threat to health as narcotic and psychotropic substances.

In order to find out the substance contents the corresponding laboratory tests are being carried out. In 2015 alone there was done the study of 2522 narcotic and psychotropic substances in the State Police Forensic Research Department. Research of narcotic situations show, that despite the youngsters' getting into medical institutions, they are still continuing to use hallucinogenic and addictive substances. The use of Spice and other synthetic Cannabinoids provokes the development of such psychic diseases, that traditionally do not develop in humans. Initially one is exposed to the hallucinogenic activity of the substance, and then it is followed by psychic disorders like schizophrenia." (Likums "Par narkotisko un psihotropo vielu un zāļu likumīgās aprites kārtību", 1996) Specialists admit, that these substances are released from the body slowly, and hence the tendency to try them, though even only once, is wild. The effect of synthetic cannabinoids is considered to be at least 5 times stronger than the effect of THC, the main ingredient in marijuana, thereby the psychoactive effect is formed faster - it starts three to five minutes after its use and lasts on average for one to eight hours . 
Andrejs Vilks. Prevention of Psychoactive Substance use among Young People as a Socially Pedagogical Problem

\section{Risk groups of new psychoactive substances in the community}

Chances to buy new psychoactive substances are very simple - they are sold even in the Internet, the market places quite often are organized in the partment buildings or in their neighbourhood. In 2015 it was still topical to use open and hidden (DARKNET) Internet resources, postal and courier deliveries in the illicit circulation of new psychoactive substances and controlled ubstances ( for instance, in March 2015 there was detected the ordering of hallucinogenic mushrooms in the hidden website (Darknet) with the delivery from Poland) Pārskats, 2016). As a result, any person can purchase the psychoactive substances, children and youngsters as well and who are considered to be the greatest groups at risk.

Article 49 of the Law on Protection of Children's Rights says, that a child is not allowed to use narcotic, psychotropic, toxic and other intoxicating substances (Bērnu tiesību aizsardzības likums,1998). The child has to be protected against the use of narcotic, psychotropic, toxic and other intoxicating substances, which have the negative effect on the body due to the manufacturing of such substances, their marketing and any kind of distribution. The second part of Article 49 of the same law, in its turn, envisages, that the guilty party is criminally responsible for delivering narcotic, psychotropic or other intoxicating substances at the child's disposal, or creating such conditions when these substances have become freely available to the child, for encouraging the child to use narcotic, psychotropic, toxic or other intoxicating substances, for the child's involvement into the use of such substances, or their distribution(Bērnu tiesību aizsardzības likums).

Mass media plays a great role, and they would have to pay more attention to the publications. The information rendered by printed and electronic mass media powerfully effects the children's and teenagers' psyche. All in all, they have a notable impact on people's views and opinions and depic the public social norms. Children and minors are the least protected and the greatest group at risk in the community, perceiving the opinions on the positive aspects of drugs and accepting them as the absolutely right ones. Undoubtedly, a child, still underaged, is not matured either physically, or emotionally, and his/her point of view is formed by perceiving the values, moral norms and opinions of the people around. Thus, there is a call for action at EU level to protect the children. One should provide the legal regulation which is powerful and effective (Eiropas Komisija stiprinās noteikumus).

The study ,Situation in the field of drugs and drug addiction problems in Latvia up to 2014", carried out by the Disease Prevention and Control Centre, has concluded, that 198000 population in Latvia had tried to use some drug. The sampling error is $1 \%$ to one or another side, i.e., by $95 \%$ probability we can 
assert, that $13,3-15,3 \%$ or $184-212000$ of Latvian population have tried one or another illicit substance. The greatest number of drug attempts has been observed among males at the age of 15-34 years, besides, $11 \%$ males and 5\% females have used them within the last year. Like in the previous years marijuana or hashish are still among the most prevalent illicit narcotic substances - tried by $12,5 \%$ of population. Next most prevalent drug following marijuana is ecstasy (tried by $2,7 \%)$, amphetamines $(2,3 \%)$, cocaine $(1,5 \%)$ and different opioids $(1,1 \%)$. LSD, other hallucinogenics and heroin are lesser spread substances - tried by lesser than $1 \%$ of population (Situācija narkotiku un narkomānijas problēmas jomā Latvijā līdz 2014.gadam). From the abovementioned we can conclude, that the most ,active" users of drugs in our society are the people of the younger generation - the average age being from 15 to 34 years. In the study it was found out, that , at a comparatively young age there is used also marijuana, opioids, different hallucinogens, as well as new psychoactive substances, or the so-called new drugs, not mentioned in the list of addiction-inducing drug list: at least $34 \%$ have tried them being under 18 years old. Amphetamines are usually tried (56\%) at the age of 19-25 years, but only $33 \%$ - prior to it. Cocaine is usually tried even at a later age - usually (44\%) it is at the age of 21-15 years". (Situācija narkotiku un narkomānijas problēmas jomā Latvijā līdz 2014.gadam).

We can admit, that just these new psychoactive substances, or new drugs, are tried and/or used by the greatest group at risk - children. The reason why majority of children and youngsters use the new drugs is their easy availability. Besides, we have to point to the low price of the psychoactive substances, which is lower than for the other narcotic substances.

\section{Spread of new psychoactive substances in Latvia}

The average age of the drug users is from 15 to 34 years. It means, that the new generation is the most active users, the children - the greatest group at risk in the society. It is admitted, that ,the chief factors which expose the children to the higher risk for drug use, causing probable consequences in future, are: previous negative experience in the family and certain psychological problems resulting from them; - a lesser degree of the sense of responsibility; behavioural disorders; - lack of possibilities to spend one's leisure time; psychological microclimate in the family; - limited possibilities to acquire positive emotions, etc." (Narkotisko un psihotropo vielu un to atkarības izplatības ierobežošanas un kontroles pamatnostādnes 2011. - 2017).

We can admit, that a great role is played also by the specific place, the town where the drugs, especially the new psychoactive substances are spread and used. One cannot deny, that the new drugs are first spread in the bigger 
towns and only then further on, possibly, in the rural territory. Most commonly the drugs have been tried and used by those who live in Riga, while in smaller towns the number of drug users is slightly lesser, but in the country places - the least one. It means, that one should pay more attention to controlling the spreading of drugs in Riga, which demonstrates the most alarming figures on the use of drugs among the young people. In Riga almost every second young male of the age 15-34 years has tried some drug - 51\% (Situācija narkotiku un narkomānijas problēmas jomā Latvijā līdz 2014.gadam).

In 2014 „Narcotic drugs and psychotropic substances and their dependencies containment and control guidelines for 2011 to 2017" were developed, thereby already four years before there had been known the facts on the risk what the introduction of new psychotropic substances cause, as well as there had been know ,the gaps" in legislation and in the system of drug control and restriction.

It was pointed out in „Narcotic drugs and psychotropic substances and their dependencies containment and control guidelines for 2011 to 2017", that in Latvian situation, to a greater extent than in other countries of the world, the people at young age, youngsters and children, because of their socially psychological peculiarities are the most exposed part of society to the spread of drugs (Legālās" nāves pieprasījums un piedāvājums).

Considering the spread of narcotic substances in the last years, on November 14, 2013, the amendments to the Law „Of narcotic drugs, psychotropic substances and drug legal procedures for the circulation" were adopted. The essence of the amendements was such. Firstly, they define the concept of the new psychoactive substance. Secondly, they open wider possibilities to restrict and prohibit the selling of new psychoactive substances. The following alterations have been introduced in Article I:

„(2) By decision of Disease Prevention and Control Centre for the period up to 12 months from the date the decision comes into force, it is possible to prohibit or restrict the manufacturing, purchasing, storage, transportation, delivery or distribution of such new psychoactive substances or its containing products, which are not included into the lists of controlled narcotic substances, psychotropic substances and precursos in Latvia, and about which there has been acquired the information from the European Early Warning System, or the conclusion received from the Forensic Expertise institution on the new psychoactive substances. The decision comes into force on the next day after its being published in the gazette „Latvijas Vēstnesis”.

(3) New psychoactive substances or their containing products whose circulation is prohibited or restricted according to the decision mentioned in the second part of this Article have to be returned back by the physical or legal 
person to the State police within three working days since the decision has come into force.

(4) Storage of such new psychoactive substances or their containing products whose circulation is prohibited or restricted according to the decision mentioned in the second part of the Article is provided by the State police or the investigating authority, who within the framework of the criminal process has removed the new psychoactive substances or their containing products.

(5) If the new psychoactive substances are included into some lists of controlled narcotic substances, psychotropic substances or precursors in Latvia, the investigating authority makes a decision on the destruction of these substances or their containing products. The execution of the decision mentioned is provided by the State Police, according to the procedures set out in the normative act on the material evidence and the arrested property.

(6) If the new psychoactive substances are not included into any lists of controlled narcotic substances, psychotropic substances or presursors in Latvia, the State Police or the investigating authority makes a decision on the procedures of the return of this substance or their containing product to the owner or its legal possessor. The State Police or the investigating authority notifies the owner or its legal posessor, at the same time giving information on the destruction of the new psychoactive substances and their containing products, if the owner or the legal possessor within two months since the notification has not removed them. The State Police of the investigating authority return back the new psychoactive substances or their containing products to the owner or their legal possessor, or destroy them, drawing up the act on it ." (Likuma grozījumi un "legālo" narkotiku aprite ).

\section{Socially pedagogical aspects of prevention of the use of psychoactive substances}

The most essential socially pedagogical problem in prevention of the use of psychoactive substances deals with creation of a favourable environment in the educational establishment and neutralization of conditions which encourage the young people to use drugs and alcohol. The duties of the social educator, which most directly would be related to prevention of the use of psychoactive substances, might be as follows:

1) to identify social and material problems of families and their effect on the child and young people's lives and different forms of activities;

2) to assess the probabilities of risk factors and their level in the family, school, among peers and their effect on the children's socialisation process; 
Andrejs Vilks. Prevention of Psychoactive Substance use among Young People as a Socially Pedagogical Problem

3) to investigate the children's and young people's socialisation conditions and risk factors at school, family and informal environment;

4) to identify social-pedagogical possibilities at educational establishments for the implementation of resocialisation measures for children who have started to use psychoactive substances;

5) to attach the possible resources and partners (persons, institutions) and to identify their forms of activities and contents in neutralization of addiction from psychoactive substances;

6) to plan and implement certain social-pedagogical activities in neutralization of addiction from psychoactive substances among children and young people;

7) to carry out activities by decreasing and preventing the existing risk factors of drug addiction of children and young people in their leisure environment, among them including cooperation partners between institutions;

8) to plan and carry out social rehabilitation measures for children who have started to use psychoactive substances in their out-of-scool leisure time;

9) to cooperate with social service agencies, Orphan's Court and other national and municipal institutions, promoting the topical social needs provision for children and young people;

10) to promote strenghening of children's and young people's responsibility and positive manifestations in the resocialization process.

Social educators who work with those children, who have started to use psychoactive substances, have to know the negative effect of these substances on their users, they have to be able to identify them. Undoubtedly, social educators have to possess excellent communication skills, to be patient and tolerant.

Taking into account the ever increasing spreading of the new psychoactive substances, marijuana and hashish not only among the youngsters, but schoolchildren as well, the issue on the establishing of the national level addiction prevention system not only for the implementation of general, but also selective prevention activities.

No doubt, that the law and its amendments alone do not solve the problem, why children and youngsters want to try and use new narcotic substances, and why they want to get intoxicated. To decrease both the demand, and supply, first of all we have to decrease and eradicate the children and youngsters' wish to become intoxicated, the wish to try. The wish to get intoxicated is releated to the 
wish to escape from the family problems or problems at school. Identification and solution of these problems is one of the social educator's competences.

\section{Conclusions}

New psychoactive substances, whose effect changes the way how a person feels, thinks or behaves, including the changes on the children's psyche, their emotional and physical condition. They imitate the traditional effect of narcotic substances. However, the trading volume of the new psychoactive substances after adoption of the new legal regulation in 2014, has decrease. The new psychoactive substances are sold as herbal mixtures, in such a way hiding the real contents of the mixtures. The use of Spice and other synthetic cannabionides provokes the development of a new type of psychic diseases. Specialists have admitted, that these substances are removed from the body very slowly, and consequently, the craving to have them, even if trying once, is wild. The highest number of drug users is seen among young people and young males at the ages of 15-34 years. Marijuana, opioids, different hallucinogens, as well as the new psychoactive substances, not mentioned in the list of addictive substances are being used at an even younger age. At least one third of young people (34\%) have tried them before reaching 18 years of age. In Riga drugs have been tried by every second 15-34 years old man. We have to admit, that the legal regulation in Latvia in relation to such substances is sufficiently effective. We can conclude, that there has not been worked out and accepted special socially-pedagogical and preventive methodology in work with youngsters and children - users of new psychoactive substances.

\section{References}

Bērnu tiesību aizsardzības likums. Latvijas Vēstnesis Nr.199/200, 08.07.1998.

Eiropas Komisija stiprinās noteikumus, lai cīnìtos pret bīstamām jaunām sintētiskajām narkotikām. Pieejams: http://www.es.gov.lv/news/eiropas-komisija-stiprinasnoteikumus-lai-cinitos-pret-bistamam-jaunam-sintetiskajam-narkotikam

Konovālovs J., Ivančiks, J., Miķelsons, U. Narkotiku noziedzības izmeklēšana. Rīga, LPA, 1995

Legālās nāves pieprasījums un piedāvājums (II). Pieejams:

http://www.lvportals.lv/print.php?id=262085 .

Legālās un nelegālās apreibinošās vielas. Pieejams:

http://www.drugs.ie/lv/informcija_par_narkotikam/narkotiku_veidi/.

Likuma grozījumi un "legālo" narkotiku aprite. Pieejams: http://www.lvportals.lv/visi/ skaidrojumi/259982-likuma-grozijumi-un-legalo-narkotiku-aprite/.

Likums "Par narkotisko un psihotropo vielu un zālu likumīgās aprites kārtību". Latvijas Vēstnesis Nr.89, 23.05.1996 
Andrejs Vilks. Prevention of Psychoactive Substance use among Young People as a Socially Pedagogical Problem

Narkotisko un psihotropo vielu un to atkarības izplatības ierobežošanas un kontroles pamatnostādnes 2011. - 2017. gadam (informatīvā daļa). Pieejams: http://www.emcdda.europa.eu/attachements.cfm/att_138748_EN_Latvia\%20 Programme\%202011-2017\%20Latvian.pdf

Pārskats par Valsts policijas darbu 2015. gadā. Rīga, Valsts policija, 2016.

Sargi sevi-narkotiskās un psihotropās vielas. Pieejams: http://www.sargi-sevi.lv/?id=150.

Sintētiskie kanabionīdi. Pieejams:

http://www.vm.gov.lv/images/userfiles/sintetiskie_kanabinoidi.pdf.

Situācija narkotiku un narkomānijas problēmas jomā Latvijā līdz 2014.gadam. Pieejams: http://www.spkc.gov.lv/atkaribu-slimibu-petijumi-un-zinojumi/. 